heiten diskutiert. Bei den sehr seltenen Leydig-Zelltumoren handelte es sich um 6 jährige Knaben mit weit fortgesohrittener Acceleration. Es sind in der Regel gutartige Tumoren. - Die beiden Nebennierenrindencarcinome führten trotz makroskopisch guter Abgrenzung in beiden Fällen zum Exitus. Dabei wurde das Problem der Therapie insbesondere mit dem Insecticid $o^{\prime}-p^{\prime}$-DDD diskutiert. Anhand des Nebennierenrindenadenoms, das eine sehr seltene Kombination mit AGS-Symptomatik, zum Teil auch Feminisierung zeigte, wurden die patho-histologischen Probleme der Ubergänge zwischen Carcinom und Adenom diskutiert.

\title{
31. Prognose und biologische Probleme des Neuroblastoms
}

Bettina Maas und H. Mmdenberger*-Tübingen

\author{
Prognosis and Biological Problems of Neuroblastoma
}

Summary. Amongst malignant embryonic tumours neuroblastomas occupy a special place, mainly because from time to time genuine cases of spontaneous cure have been described. There is increasing clinical and experimental evidence that immunological reactions play a part in this. However, the knowledge gained in this field is not yet sufficient to provide a basis for therapy. However, since cytostatic therapy and radiotherapy, which are often combined with corticosteroids, constitute an immunosuppressive therapy, one has to ask oneself whether this now customary treatment of neuroblastomas does not in fact do more harm than good.

Zusammenfassung. Das Neuroblastom nimmt unter den malignen embryonalen Tumoren eine Sonderstellung ein, vor allem auch deshalb, weil immer wieder Fälle echter, spontaner Heilung beschrieben werden. Es mehren sich neben klinischen auch die experimentellen Hinweise, daß hierbei immunologische Reaktionen eine Rolle spielen. Zwar reichen die in dieser Hinsicht gewonnenen Erkenntnisse für neue therapeutische Ansatzpunkte derzeit nicht aus. Da aber eine cytostatische Behandlung und eine Bestrahlung, die oftmals mit einer Steroidbehandlung kombiniert wird, de facto eine Immunsuppression darstellt, wird man sich doch fragen müssen, ob die derzeit übliche Therapie des Neuroblastoms nicht in Einzelfällen mehr schadet als nützt.

\section{Probleme der Diagnostik und Therapie kindlicher Lebertumoren}

\author{
C. Herfarth* und H. van Lessen-Freiburg i. Br.
}

\section{Problems of Diagnosis and Therapy of Hepatic Tumours in Children}

Summary. There is no cause for therapeutic nihilism when dealing with malignant tumours of the liver, so long as no metastases exist and the tumour is confined to one lobe. The classification of Baggenstoss (1970) divides hepatic tumours into benign and malignant epithelial and mesenchymal growths. Clinically 